\title{
Memorias de un fauno en su jardín
}

\author{
A Rachel, flor de invernadero \\ "Si quieres ser feliz un dia: emborráchate; \\ si quieres ser feliz un año: cásate; \\ si quieres ser feliz toda la vida: sé jardinero". \\ (Proverbio chino, citado por Facundo Cabral)
}

\section{El SOS de algunas plantas}

Eran alrededor de la una y media de la tarde; yo acaba de jugar básquetbol en una de las canchas de la UCA, cuando recibí el primer llamado de auxilio de parte de algunas plantas. Ocurrió de esta manera: al salir del complejo deportivo, tuve un primer impulso de atravesar la calle para tomar en la acera de enfrente el bus de la ruta $\mathbf{4 4}$ que habría de llevarme a Antiguo Cuscatlán. Obvio: ya estaba cansado y aquel era el camino más corto y rápido para llegar a mi casa. Sin embargo, algo me hizo desistir. "Voy a irme por arriba a tomar el bus en Jardines de Guadalupe..." Esto sí era, a todas luces, una tontería: yo debía caminar en subida más de medio kilómetro... ¡Y, además cansado!

Otra zona de mis adentros me reprochaba: "—No seás tonto, ¡Qué necesidad tenés de hacer más ejercicio? ¿Qué querés probar?" Aunque el otro yo "necio" me seguía empujando a tomar el camino más largo y cansino.

Empecé a caminar casi con desgano por la acera izquierda de la calle de acceso al interior de la UCA. "- iNo, por aquí no; pasate a la otra acera!", volvió a hacerse oír el imperativo, y tuve que obedecer. Cuando ya abría caminado por la acera derecha me di cuenta que Don Rosendo, el jardidero que hasta hacía poco tiempo era el encargado del predio de jardín situado frente a mi cubículo, estaba cortando de raíz unos pequeños cipreses pequeños y redondeados, que adomaban el arriate del centro de la calle.

“-Ve, don Rosendo, ¿Y ahora está jardineando por aquí?" “-Sí, para aquí me han mandado..." Y mientras platicábamos, volví de pronto la vista y vi un 
gallito (Bromelia) prendido en uno de los cipreses recién cortados "- ¿Me puedo llevar este gallito?" "-Sí, lléveselo; total: a estos cipreses los van a venir a cargar hoy omañana en un camión para hacerlos leña y quemarlos..!"

Al inclinarme a cortar la planta me di cuenta, con gran sorpresa, de que en algunos de los cipreses cortados había una gran cantidad de orquídeas pequeñas que yo no conocía. "-Me voy a llevar estas plantas también." "- ¡Llévese todas las que quiera!”. Logré arrancar como unas quince plantitas que habían estado aferradas con sus raicitas a los troncos y ramas de unos dos o tres cipreses. Contento, continué el camino a mi casa con el manojo de orquídeas que acababa de salvar de la hoguera. Al llegar, ni corto ni perezoso, empecé a amarar con alambre a mis nuevas amigas a los troncos de algunos pinos y otros árboles.

Al día siguiente volví a salir del complejo deportivo, después de mi acostumbrado mascón de básquetbol, y de nuevo también sentí el mismo impulso del día anterior. "-No puede ser: ¡si ya agarré todas las orquídeas de los cipreses cortados!" Al llegar hasta donde estaba Don Rosendo, le pregunté si habían otros árboles cortados durante los días anteriores. "-Sí, allá en ese talúd que da a la cancha de fútbol están los cipreses que corté hace unos días. Vaya a ver si quiere ..." Me asomé al talúd, y entre algunos cipreses fui descubriendo más orquídeas del mismo tipo de antes. Las tomé y al llegar a mi casa repetí la operación de sujetarlas con alambres o pitas a los troncos de mis árboles.

En total, creo que salvé durante el operativo unas veinte orquídeas; pero, sobre todo, tuve la clara impresión que ellas me habían enviado su SOS para que las salvara... iporque yo creo en la comunicación telepática con las plantas! Lo hermoso estuvo en que no paró ahí la cosa: las orquídeas, esas a las que de ahí en adelante llamé mis "huérfanas", continuaron con sus llamados de auxilio.

El segundo llamado ocurrió unos días después del rescate ya narrado. Caminaba yo con mi amiga Luisa desde su oficina al restaurante donde ibamos a almorzar, cuando me dio por contarle a ella el mágico episodio que recién acababa yo de protagonizar."-Fijate que hace unos días unas orquídeas se comunicaron conmigo para que las salvara... Esas orquídeas eran parecidas a..." Levanté la vista buscando alguna plantita que se le pareciera a las que estaba mencionando, cuando me di cuenta de que encima de mí estaban apiñadas en una rama larga, unas orquídeas exactamente iguales a mis "huérfanas". "- ¡De estas son las orquídeas de que te estoy hablando! ¡Son mis huérfanas!”.

Yo había pasado por ahí cientos de veces, pero fue hasta ese momento en que le contaba a Luisa de mi rescate, que se me hicieron presentes esas orquídeas de la misma clase que las de la UCA. Emocionado, terminé de contarle a Luisa la aventura, y cerré el episodio diciéndole: "—Quizás éstas también corren peligro. Ojalá que me avisen a tiempo si van a ser cortadas o maltradas". 
Durante los días siguientes que pasé por ese lugar - la convergencia de la avenida Sierra Nevada y la calle Los Sisimiles no dejaba de echar una mirada al tronco donde se hospedaban las orquídeas. Me asaltaba la idea de alargar la mano y arrancar algunas matitas; pero... "-Es mejor que estén en su medio natural. No tengo por qué llevármelas a otra parte". Sin embargo, una inquietud me asaltaba: "-Cualquier rato van a arrancarlas y botarlas... Conociendo como es nuestra gente..."

En esos días no había ninguna evidencia de que mis temores fueran a cumplirse; pero, un día de tantos... unos obreros trabajaban en la acera en cuyo arriate se encontraba el árbol —un calistemo, por cierto- anfitrión de orquídeas. Los albañiles hacían reparaciones dentro y fuera de la casa; había cemento y arena por todos lados. "- ¡Ah, ahí está el peligro! - Me dije- ¡Avísenme, entonces, si les hacen algo a ustedes o al árbol..."

Dicho y hecho, al día siguiente que pasé, el calistemo había perdido parte de sus ramas, cargadas de orquídeas y otras "parásitas". Los restos de la "poda" esperaban pacientemente en la cama de un camión pequeño para ser trasladados al botadero $o$ al pante de leña. "- iPuedo cortar unas plantitas que estan prendidas en los troncos?", pregunté a uno de los obreros... y casi sin esperar respuesta me encaramé al camión y comencé a arrancar orquídeas, bromelias y helechos que aferraban aún a las ramas del calistemo.

Con extrañeza, los trabajadores veían mi afán. "-Viejo loco— han de haber pensado-, iqué cosas las que le gustan! ¿Para qué querrá ese monte?”, pero en esa ocasión fueron otras diez o quince orquídeas más las que rescaté, aparte de algunos helechos, bromelias y tapetes de musgo. Todavía quedó el tronco mayor del calistemo y un pedazo de rama con algunas orquídeas: parecía un muñón, un brazo mutilado sin mano y deforme, pero ¡aún se aglomeraban ahí algunas matitas de orquídea. (Espero estar presente a la hora en que decidan cortarlas.)

Ironía del caso: luego de que los obreros hubieron terminado la remodelación de la casa, algún pintor de brocha no tan gorda dibujó sobre la fachada unas ramitas y hojas verdes, con flores de varios colores. "- iVaya -me dije-, arrancan las flores y plantas de verdad para pintar estos ramales y flores tan cursis! apuesto a que ni el dueño de la casa ni los obreros cayeron en la cuenta de la "pasada" irónica que acaban de protagonizar. ¡Así es nuestra gente..!

(Una curiosidad botánica que debo resolver: a pocos metros del calistemo en cuestión estaba un árbol de San Andrés que tenía en una de sus ramas más altas algo así como una planta parásita; las hojas redondas y rechonchas de esa plantas contrastaban con las hojas finas y alargadas del San Andrés. Un día de tantos, podaron el San Andrés y se llevaron de encuentro la planta (¿parásita?). Pensé, entonces, que a mis paisanos les da igual tener ante los ojos alguna rareza, de esas. Ellos pasan delante de tantas cosas raras, sutiles o hermosas, 
pero sin reparar en ellas. A fin de cuentas, no se pierden de nada por que sus sentidos no están preparados para captarlas: ¡Así son de toscos...!" Pensé, además, que la simbiosis aquella entre la planta de orejas de ratón gigante y el San Andrés ya se había perdido para siempre, ahí... en la encrucijada de aquellas dos calles tan transitadas. Pero un día en que pasé observando los árboles, me di cuenta de que aquella planta parásita o injertada también estaba creciendo, escondida, sobre la rama de un maquilishuat cercano al San Andrés...!Ojalá que no corra la misma suerte que su hermana; por lo menos antes de que yo averigüe de qué fenómeno se trata!

Algunos días después de los respectivos rescates, las "huérfanas" comenzaron a dar flores. Cada matita dio una flor de unos $5 \mathrm{~cm}$, color anaranjado, con vetas rojas y blancas. Una orquídea muy linda, pero cuyo nombre cientifico ignoro; pertenece también a esas flores curiosas que se aprecian mejor a través de la lupa.

El acopio de mis "huérfanas" aumentó cuando las señoras de Jayaque, vendedoras de "parásitas", me llevaron un manojo de quince plantitas más. Sin embargo, varia fue la suerte de todas ellas: unas se secaron al poco de ponerlas en los árboles; otras, florecieron y luego se secaron, en una especie de canto de cisne. En resumen, tengo por ahora unas seis matitas bien vivas y sanas; con ellas haré, andando el tiempo, la propagación de la especie, hasta que tal vez llegue a recuperar el número original de mis "huérfanas" que llevé a mi terreno.

Con los helechos me han ocurrido igualmente reclamos de auxilio; de modo que al tercer SOS he de asignárselo a un helecho prendido en un árbol de calistemo, frente a unas aulas magnas de la UCA...

Yo llevaba meses haciendo el esfuerzo de no arrancar el tal helecho; pero un día de principios del inviemo de este año 1998, me decidí ha hacerlo, calculando que no hubiera ningún vigilante por ahí. Cuál no sería mi sorpresa cuando exactamente al otro día habían cortado el calistemo y otros árboles más; los troncos y ramas yacían en una de las aceras de la calle de circunvalación de la UCA. Sin tardanza alguna, me dediqué a cortar cuanto helecho y tapete de musgo se pusieran a mi alcance... así que mi terreno tiene una nueva provisión de esas plantas... ¡Y fue el helecho del calistemo frente al aula magna No. 2 el que me dio el aviso.

\section{Enseñanzas de vida y muerte}

Ya he dicho en otras oportunidades que en mi terreno de Antiguo Cuscatlán tengo mi fracción envasada de montaña, mi parque "El Imposible" en miniatura, mi solar encantado donde se entremezclan cinco o seis dimensiones; algo así como un "cuadrilátero" de Las Bermudas, túnel o pasadizo para remontarse al pasado o para hacerse contemporáneo del futuro. "Macondo" le han llamado 
desde hace tiempo mis amigos, porque saben que ahí Arcadio y Ursula se pasman aún tocando y admirando el hielo que les llevó alguna vez el Melquíades de sus sueños de niños; descubren una y mil veces la redondez de la tierra, y escuchan atentos los latines de algún fantasma que ronda el árbol más alto del solar.

Ahí en el silencio de la noche poblado de grillos, o entre rosetas de luz y de sombras de mediodía caluroso y húmedo, como en una pequeñísima Amazonia, puede uno aprender las interminables lecciones magistrales de las plantas, de las piedras y de los animales.

Y ya en un lenguaje menos poético, y algo más frío, hablaré de esas lecciones en que tengo como maestros y maestras a los seres animados e inanimados, diminutos y grandes, que pueblan mi solar. Una primera gran lección que he aprendido de la relación que se establece con las plantas es que no se trata sólo de un compromiso: el compromiso de regarlas, podarlas, abonarlas; porque llega uno a encariñarse de tal manera con ellas, que el cuido y dedicación se convierten en un verdadero deleite. Cuando uno va observando cómo crece una plantita diminuta, sobre un tronco que le sirve de apoyo, o cuando uno comprueba con tristeza que se secó aquella otra planta o que los zompopos acabaron con otra de más allá, entonces, uno puede ir cayendo cada vez más en la cuenta de que existe entre ellas y uno un vínculo tan fuerte, que no es exagerado llamarlo cariño y hasta enamoramiento o pasión.

Porque dedicarse al cuido de las plantas puede llegar a convertirse en pasión, en parte fundamental de la realización del propio ser. Uno se siente pleno, feliz, volcado completamente a ellas. Y entonces operan los cortocircuitos: se comprende, por ejemplo, cómo el amor a los hijos es y debe ser como el que se le tiene a las plantas. Los dos amores son, por así decirlo, intercambiables; el uno es la metáfora del otro.

Pero también puede establecerse otro corto circuito: el amor que se le tiene a un libro que se ha escrito o que se está escribiendo, es algo que puede asimilarse a aquel amor por los árboles y plantas; y uno puede ficcionar con que las correcciones que se le hacen al libro son como "podas", y que pueden llevarse a cabo "injertos" de otros libros o artículos propios ajenos. En fin, que el libro mismo es la propia cosecha, y que uno puede volverse una y otra vez a la lectura del libro como se saborea el fruto que más gusta.

Con todo lo anterior, ya podemos sacar algunas conclusiones: el jardinear puede convertirse en expresión no sólo del hobby por antomasia —distracción y diversión plena para el tiempo libre-, sino expresión de lo que debería ser el trabajo - todo trabajo- creativo, humanizador y plenificante (rebozante de goce y realización) para el ser humano. Un trabajo antípodas del enajenante trabajo explotador y robotizante, objeto de todas esas condenas que le dirigió a Carlos Marx. 
Con un "trabajo" de jardinero como el mío ocurre en que uno no quisiera despegarse de él; en mi caso, dejarlo para ir a las labores de la UCA, por más que ellas - cotno la de dar clases - sean algo grato para mí, es algo que me incomoda sobremanera. Comprende uno entonces lo que plantea Marcuse en su Hombre unidimencional: debería llegar la humanidad a un estadio de civilización y realización tan plenas, que se considera como un trabajo altamente remunerable, el cuido y el cultivo del jardín propio.

Una concepción así, tan avanzada, coincide plenamente con el espíritu del adagio chino que aparece como epígrafe de este artículo: si uno quiere ser feliz toada la vida, pues debe entregarse en cuerpo y alma a la labor de jardinero.

La segunda gran elección a partir del contacto con las plantas y animales de mi terreno: uno llega a distinguir con suma claridad qué o quiénes están con uno o contra uno. Si yo miro zompopos en la calle o en cualquier acera, procuro sortearlos; lo mismo hago con las hormigas y otros animalitos rastreros. Pero a los zompopos y los gusanos de mi terreno los combato a sangre y fuego. Seguido atiborro las cuevas de zompopos con un veneno fortísimo; porque si hay algo que me saca de quicio es ver retaceadas y destrozadas unas plantitas que hacía poco estaban lozanas y florecientes.

Mi furia en contra de Baco - el hermoso perro Bnxer de mi hija Ursula - iba por ahí: cuando me mordisqueaba alguna mata de platanillo o de sultanas, prácticamente saltaba sobre él para jalarle las orejas o pegarle con un cincho. "- iNo le jalés las orejas -me decía Ursula-, ¿No sabés que ellas son la parte más sensible de los perros?!", “-ipues que no me toque mis plantas, porque ellas son mi parte más sensible, y me duele que las destruyan!" La pugna con Baco terminó hace pocos meses: desgraciadamente un virus se lo consumió, apesar de los cuidos y desvelos de Ursula. Baco fue enterrado en el terreno: pasó a formar parte de los nutrientes de las plantas que a él tanto le gustaba mordisquear...

(Sin embargo, para ser justo con Baco, debo decir que de él guardo muchos recuerdos... El rostro de los Boxer es de aspecto feroz y feo: ojos inyectando sangre, cachetes de un Bull-dog. Ahora bien, el de Baco era un rostro especialmente dulce: sus ojos miraban desde el fondo de una profunda triteza, como si anunciaran por adelantado su temprana muerte; y no desagradaban del todo sus mejillas y sus dientes. Era, además, un perro extremadamente noble: a pesar de que yo le daba duro cuando me desbarataba alguna de mis plantas, parecía olvidarse pronto del castigo y era capaz de ladrar alegremente alrededor mío cuando lo llamaba para jugar. Notoria era su vocación para el juego, tanto que quizás por su espíritu jugetón, más que por hambre o ganas de fastidiar, se daba a mordisquear mis plantas... Espectáculo fascinante era ver saltar a Baco casi dos metros de altura, cuando se le "toreaba" con una gorra o cualquier otra prenda de vestir; porque Baco poseía una agilidad pasmosa, a pesar de la fuerte musculatura que llegó a desarrollar. Nuestro Boxer albino murió cuando contaba 
con poco más de un año; había luchado en silencio hasta el final. Y Arcadio me recuerda que debo poner en mi escrito que Baco nunca se quejó durante su larga y dolorosa enfermedad; sólo cuando Ursula le ponía inyeciones (yo ayudé a mi hija a ponerle dos inyecciones y antibióticos) se le oía chillar y retorcerse durante breves momentos... Ursula aún llora al recordar a su amado perro Baco, ese huésped cánido que estuvo tan poco tiempo entre nosotros. La Canela - Cana, Canoa, Canona, como también la llaman mis hijos- es la perra doberman de Arcadio; tuvo el virus antes que Baco, pero logró sobrevivir y, por ahora, es la única compañía canina que nos queda... ¿Qué recordará de aquellas dos o tres escaramuzas que tuvo con Baco? ¿Sintió la muerte de su amigo? A saber... pero cierto es que también ella, desde hace poco tiempo, nos mira con ojos de una profunda tristeza...)

¿Tengo derecho o no de agredir a un animal que me daña a mí o a mi propiedad? A veces aparecen coralillos debajo de los troncos; generalmente, los echamos con Arcadio en un bote o en una bolsa de plástico, para irlos a depositar luego a las montañas de Antiguo Cuscatlán. Sin embargo, hace unos días tuve que matar dos de ellos porque se habían metido dentro de la casa. Me dolió en el alma hacerlo, pero la norma que voy sacando cada vez más en claro es la siguiente: debo respetar a los animales que no nos agreden ni ponen peligro a nosotros, las personas de la casa o las plantas del terreno, aunque "desagradables" (a la vista, al tacto) o peligrosos: arañas, ciempiés, culebras, etc. Pero toda vez que se traspasen esa frontera o invadan nuestro espacio o "territorio", se convierten en el enemigo que se debe combatir y aun aniquilar... Así, no tengo reparo en matar y aplastar cucarachas, zancudos, moscas o cualquier otro insecto portador de enfermedades... como tampoco tengo reparo en defenderme con un palo o una piedra frente a un animal que me quiera morder.

Estoy consciente, entonces, de que yo desempeño el papel de los depredadores de la naturaleza: ellos atacan y aun matan, pero para sobrevivir y para mantener el control de poblaciones animales ( $y$ aun vegetales) que pueden llegar a convertirse en plagas.

El punto está en que se puede extrapolar esa norma, y aplicarla a la vida social y cotidiana: en El Salvador violento de la actualidad, también hay personas que no sólo se parecen a, sino que se comportan como insectos o animales que amenazan nuestra seguridad familiar o individual. Entonces, uno cae en la cuenta de que se trata de ellos o nosotros... En este orden de cosas, yo tengo muchos problemas con los motoristas de buses; porque para mí, el que vayan a alta velocidad o que se detengan más de la cuenta en una parada, constituye una agresión y un irrespeto para los derechos míos y de los usuarios. Por eso "salto" reclamando airadamente... Sé que corro peligro porque algún motorista o cobrador me puede resultar con un arma, tratando de asustarme o aun de agredirme... Pero yo corro los riesgos. 
Las leyes de funcionamiento de mi terreno me lo han "enseñado": para ser yo mismo, para que se me respete en lo que yo legítimamente quiero llegar a ser, debo abrirgne espacio, en ocasiones, con golpes y codazos... Es la "Ley del Monte", desgraciadamente... Pero, para mantenerme en la línea de lo que quiero para mí y los míos, para defender mi patrimonio o mi espacio y "territorio" vital, debo tener coraje, debo asumir riesgos... La condición humana se conquista aquí y ahora, con decisión y fiereza. Retroceder, amedrentarse, es dejar al agresor el campo libre para que haga lo que quiera con uno y con todos los demás.

Creo que, en gran medida, este dejar la inciativa al agresor es lo que está sucediendo hoy entre mis paisanos... Me contaban el otro día que un bus se entretuvo largo rato en una parada; una señora, entonces, reclamó en voz alta al busero por la tardanza. El motorista se volvió de pronto y dijo fuertón: “-iQuién habló?”... Y la señora se calló y agachó la cabeza, confundiéndose entre todos los otros acobardados pasajeros...

Quizás confluyan en esta actitud cobarde y hasta acomodaticia varios factores: los recuerdos de la pasada guerra, los condicionamientos de una sociedad secularmente autoritaria, en la que padres, maestros y autoridades de todo tipo se han hecho sentir a base de gritos, golpes y humillaciones. Puede que también contribuya el alto grado de "valeverguismo": Esa curiosa mezcla de escepticismo (ante la política y la vida humana o natural), de cobardía ( el "-iyo no fui!") y de cuasi-cinismo ("-Me vale que despellejen a mi vecino; ¡Para qué se anda metiendo en bonches!"). Quizá hasta haya una vocación al sufrimiento a la resignación: tal como enseña la iglesia católica (“一¡Ponele la otra mejilla al que te golpeó en una!"). Y tal como ha sido la visión fatalista de las cosmogonías indígenas precolombinas.

El hecho es que el Salvadoreño de hoy prefiere refugiarse en el silencio y el anonimato cuando se es objeto de alguna agresión... La respuesta violenta sólo aparecerá cuando ese salvadoreño esté con sus tragos o tenga respaldo de un grupo, de una masa. Entonces sí, ese salvadoreño se vuelve corajudo, gritón, dicharachero, respondón, enamoradizo y hasta llorón... Típico comportamiento, pues, de personalidades con problemas graves de malformación; personalidades atravesadas por algún conflicto básico aún no resuelto y que se va cargando año con año en la vida individual, y generación a generación en la vida colectiva:

Tercera lección extraída del contacto con las plantas: la persuasión de estar habitando uno en un santuario... Arboladura significa el conjunto de palos de un barco; también se refiere el término al entrecruzamiento de arcos en el interior del techo de una catedral gótica... Pues bien, en mi terreno se entrecruzan de tal manera las ramas de los árboles, que ellas parecen la arboladura de un barco, pero mejor, de una catedral. Pues, tiene la sensación de estar en una "nave": bajo el cañon y bóvedas de una iglesia o bajo el entrecruzamiento de palos, velas y jarcias de una embarcación. 
Pero esa sería la parte, podríamos decir, meramente "exterior", algo así como la composición arquitectónica... Veamos ahora aspectos relacionados más con el "interior" del "edificio"... Hace unos días llegó un señor a nuestro terreno para hacer una fumigación "ecológica": rociando ciertas sustancias orgánicas combate cucarachas, pulgas, arañas, etc, etc. Pues el señor observó nuestro terreno y nuestro hábitat, y la conclusión que sacó es la siguiente: ustedes viven en un santuario; aquí hay bastante espacio y suficientes árboles para que la misma naturaleza controle las plagas: las lagartijas, por ejemplo, mantienen limpios de bichos los rincones no sólo del terreno, sino de la misma casa. Pero, además, el entomo natural, húmedo, umbroso y cubierto en varios lugares por una gruesa capa de humus, tiene el efecto de "llamar" a los arácnidos, ciempiés, gusanos y otros bichos; porque para ellos es más sabroso, cómodo y atractivo estar en esos nichos naturales, que dentro de la casa.

Por razones de aislamiento, determinado lugar puede convertirse en una suerte de laboratorio, donde la vida ensaye formas inéditas respecto de otras partes. Así, Australia, que en un tiempo estuvo unida al conjunto Asia-Europa, se separó de ellos para seguir sus propios derroteros; entre otras cosas, los mamíferos evolucionaron ahí siguiendo la línea de los marsupiales. El canguro es, dentro de esa línea de evolución, el animal más característico de ese continente; pero también apareció el lobo Marsupial, animal parecido a sus primos de los otros continentes, pero con un marsupio o bolsa para llevar a sus crías... Madagascar, isla unida originalmete al África, se separó luego de ella y por eso quedaron aislado en Madagascar los lemures, esos eslabones vivientes entre los micoleones y los simios. También ahí se preservaron formas vegetales muy antiguas, tales como helechos - plantas antecesoras de los verdaderos árboles- los cuales conforman aún bosques muy espesos.

Ahora bien, ¿por qué la referencia a esos reservorios ecológicos, verdaderos santuarios donde la vida ensayó formas nuevas o preservó formas antiguas? Pues porque creo que mi arboleda es uno de aquellos topoi experimentales de la naturaleza. Revisemos algunas de sus características: $(a)$ está densamente poblada de árboles y bastante aislada respecto del resto de la cubierta boscosa de Antiguo Cuscatlán; (b) sus pequeñas dimensiones derivan en una alta concentración de sus poderes germanativo-creativos; algo así como si se tratara de un envasado o quintaesenciado de alguna sustancia alquímica de vida permanente.

Esto que estoy diciendo puede sonar a cuentos de hadas o duendes; pero a las pruebas me remito; por ejemplo, basta levantar una piedra o un tronco, remover la hojarasca o arrancar un pedacito de corteza de algún árbol, para que salten retorciéndose las lombrises de tierra, huyan torpemente los escarabajos de la madera o que toda una colonia de hormigas se apresure a transportar sus huevos a otra parte más segura.

En ese peculiar frasco de humus y nutrientes, la vida y la muerte bullen por 
doquier, y creo que un oído atento hasta podría escuchar el crujido de las formas animales y vegetales germinando o disolviéndose en un mismo y trenzado ciclo de vida y muerte (cuando las copas de los eucaliptos sembrados en la calle se cubrían de flores, acudían miles y miles de abejas, avispas y abejorros; entonces, su zumbido era tan fuerte que parecía el motor de un automóvil en marcha. Ahora que ya no existen esos árboles, no se escucha tan intenso el zumbido de aquellos insectos libadores de la miel; pero, en cambio, en los árboles del terreno han proliferado panales y colmenas silvestres, y sus formas caprichosas - un panal parece homo de panadero-colman casi todos los espacios disponibles).

Otro ejemplo: hace unos meses, Francisco Serrano -biólogo y ecologista de. primera línea- escribió un artículo sobre las ventajas que reportaría una reforestación sistemática en El Salvador; decía él que en Canadá y en Chile se ha logrado, a base de incentivos económicos y de concientización, que se propaguen los bosques de pinos. En nuestro país se podría hacer lo mismo —concluía Serrano-, máxime que aquí los pinos crecen tres veces más rápido que en Chile y en Canadá.

“- ¡Ajá! -me dije- ¡En mi propio terreno tengo yo la prueba de lo que sostiene el amigo articulista...!" En efecto, el pino ese que sembré hace 21 años (al poco de nacer Arcadio) y que lo he llamado el Axis Mundi ha alcanzado casi los 30 metros de altura; además, los árboles de fuego que tienen la misma edad, causan asombro por su grosor de casi dos metros...

Ahí pues, en esa mi probeta se me han crecido los árboles de tal manera que hasta podría preguntarse uno si han rebasado los límites mismos de seguridad. (Quizás ya es hora de contratar a un miquero para que cape o pode los árboles que puedan representar algún peligro...)

Bueno, lo cierto es que mi Arboleda es un santuario donde permanentemente se le rinde culto a la vida; donde cada instante se está oficiando la ceremonia esa de la vida-muerte concatenadas, como en una permanente ebullición. Ahí, entonces, tengo servida mi pequeñísima poción de caldo o sopa primordiales; tengo en un cuenco el cieno aquel —quizás el khem o barro del Nilo- de donde se originaron todas las formas de vida... Y ante ese milagro me postro y me extasío con un agradecimiento de verdad infinito.

Dado, pues, que la Arboleda es un lugar sagrado donde se puede estar llevando a cabo un experimento trascedental para la vida, la lección es que debo estar muy atento para poder contribuir muy decisivamente en su desarrollo $y$, tal vez, en su feliz culminación. Más adelante, en otro apartado, retomaré el hilo de esa idea: ¿Qué es lo que se está cociendo en ese caldero en que hierve sustancia primordial? ¿Qué saldrá de todo eso: un homúnculo al estilo del que formó Wagner, el fámulo del Fausto de Goethe? Por ahora, voy a continuar con algunas lecciones más, derivadas del contacto estrecho con los árboles y plantas de mi arboleda. 
Cuarta lección: para quien sabe percibir, las plantas pueden ser fuente de los más variados y profundos sentimientos y emociones: relacionados con la experiencia estética, con vivencias de temura y con persuasiones casi mágicas o místicas acerca de la seguridad propia y de los suyos.

En cuanto a lo estético, he de comenzar diciendo que mi Arboleda puede verse como un fresco natural y viviente, una composición animada cuyos módulos han sido en las más diversas posiciones. La cosa es que, dependiendo de la esquina o ángulo que uno escoja, así resaltarán formas, volúmenes y colores; podrán verse mejor los nidos de las ardillas, y apreciar el colorido de algunas flores que se empeñan en adomar las copas de lo árboles más altos.

Ya hablaba yo de la arboladura o entrecruzamiento de ramas, formando arcos como los de una iglesia; ahora quiero insistir en ese carácter barroco - "abierto" de la composición arbórea... Dice Umberto Eco en su Obra Abierta que lo propio de las obras artísticas barrocas (escultura, pintura y aun música y literatura) es su apertura: no sólo permiten el punto de vista único como las obras clasicistas, donde todo parece estar ya hecho, conformando, y frente a las cuales al contemplador no le toca sino amoldarse a lo prescrito por el autor; en ellas, un contemplador puede ubicarse buscando un ángulo visual u otro. Dependiendo, entonces, de los diferentes puntos de vista, así producirá la obra efectos llamativos y variados. El entrecruzamiento de formas y vólumenes (sobre todo en las obras escultóricas) hará que la luz sugiera la aparición de figuras a cual más extrañas. Pero será el espectador quien encuentre y complete los diferentes "mensajes". Se delega, pues, en el espectador un papel sumamente importante; él resulta siendo un verdadero co-creador... Hasta ahí más o menos lo planteado, más o menos, por Eco.

En mi Arboleda la composición es abigarrada - recurrencia barroca la mía, ¿no?-: las ramas de ciertos árboles ya han sido cubiertas casi plenamente por filodendros de varios tipos: ahí hay manos de león, brasil, piñanona, corazoncitos y carita de burro; ahí el cactus trepador tiene la osadía de florecer sobre las ramas más altas del pino Axis Mundi y otros, y sólo levantando bien la vista pueden apreciarse sus hermosas flores: una campanas enormes de $15 \mathrm{~cm}$ de diámetro y de color amarillento con festones blancos. En otra parte, una enredadera espinosa que parece brezo, se ha apoderado de un pino hasta casi secarlo; sus flores rojas aparecen muy alto, buscando la luz del sol...

Pero la "camivora" de entre todas las trepadoras es la veranera de flores anaranjadas; ella se encaramó ya encima de varios árboles frutales y se los "chupó" materialmente: un almendro, un marañón amarillo, un patemo y un aguacate que lucha aún por mantener sus ramas fuera del alcance de la fatal enredadera... El tronco de la devoradora es ya de un grosor considerable como el de un árbol, y a mí sólo me recuerda la veranera que está en la biblioteca Gallardo... porque por ese camino va la mía. 
Bueno, la voracidad de la veranera es tal que un pino alto y no tan delgado se ha doblegado por el peso de la planta huésped, y yo creo que está a punto de quebrarse o setcarse... El colmo es que los tentáculos espinosos de nuestra "carnívora" ya están buscando al Axis Mundi, de modo que a la vuelta de algunos años también ese pino va a ser invadido... Ahora bien, ¿ $i$ por qué tolero a esa veranera invasora? ¿No que es una amenaza para los árboles cercanos a ella?

Por lo demás, ciertamente no es todo lo estético que se diga la ramazón o chaparro que se ha formado sobre la terraza que da al cuarto de Cayo... Sin embargo, en este caso, lo feo equivale sólo a las prosaicas barillas de un paraguas o a la armazón de alambre del interior de una piñata. Ese feo chaparro es el necesario sostén de varias bellezas: por de pronto, en él se esconden cantidad de nidos de tortolitas y de palomas ala blanca; de él cuelgan panales... Además, gran parte de la maraña de bejucos reposa sobre la mitad del techo de la casa, sirviendo como un colchón protector y refrigerante ante los rayos del sol.

Lo más asombroso de todo esto es que cuando la veranera florece (durante los meses de enero a abril, aproximadamente), se cubren de un hermosísimo manto anaranjado salmón los árboles y el techo de la casa. Aparece, entonces, la tela multicolor y alegre de una sombrilla tropical y playera... Pero, además, para contemplar en toda su belleza el espectáculo, hay que salir a la calle, a situarse a varias cuadras de distancia, en alguna parte de las nuevas colonias de Antiguo Cuscatlán... Entonces, la carpa anaranjada reluce con todo su esplendor, y uno piensa: "- ¡Sólo por ver esto vale la pena aguantar un poco de molestias que mi veranera "carnivora ocasiona".

De hecho, todo el conjunto de los pinos más altos y de los árboles de fuego floreados puede ser mejor apreciado si se contempla desde algún lugar lejano, incluso desde alguna montaña de las que rodean Antiguo Cuscatlán... La vastedad de la arboleda le invita, le pide a uno de contemplador que escoja y ensaye las perspectivas más caprichosas. Ella misma lo insta a uno a ser como el pintor buscando el mejor ángulo para su cuadro; ella empuja a ser artista.

Para mí, gran parte de la dicha que me proporciona la Arboleda consiste en andar buscando vistas vuevas; aunque yo ya tengo mi perspectiva preferida; y cuando llegan mis amigos es a ese lugar adonde los llevo, porque ahí puede apreciarse con toda su esplendorosa belleza ese mural de mi arboleda... Y no creo exagerar al decir que ahí hay pinceladas impresionistas y hasta cubistas. Ahí el pintor Naif o primitivista podría encandilarse y entregarse durante días y aun semanas a tratar de reproducir todo ese trenzado de lianas, bejucos y hojas diminutas, alternando con las gigantescas... Ahí, desde ese mi rincón recorre la mirada todos los niveles de la elvación; porque, a medida que uno se embebe en lo físico y natural, pueden ir brotando emociones y sensaciones cada vez más sutiles y delicadas en el orden espiritual... 
Para no cansar más con respecto a los efectos plástico-estéticos suscitados por las plantas, voy a concluir diciendo que mi arboleda es muy fotogénica: las fotos donde los árboles y plantas aparecen en primer plano o como fondo de personas y animales son especialmente llamativas; aun en las fotos blanco y negro resaltan lo gigantesco de las hojas de la mano de león o los juegos de luces y sombras. No digamos las fotos a colores: en ellas impresionan los variados tonos de verde, contrastado con un mosaico de rojos y amarillos de las flores. Total que cualquiera sale "bonito" con un decorado o con un fondo como ese.

En lo referente a los sentimientos de ternura, he de decir que me puede enternecer hasta las lágrimas el comprobar cómo ha logrado progresar una plantita que yo ya daba por muerta, o cómo apareció de pronto un caracol, cuando ya parecía que esos animalitos se habían marchado definitivamente del jardín... La suavidad y la delicadeza, asociadas al trato con las plantas, pueden predisponer para que afloren sentimientos tan hermosos como la ternura. En ese marco, voy a presentar ahora unos poemas inéditos: tres dedicados a mi hija Ursula y otro dedicado a mi hijo William Alexander, muerto en 1992.

Aunque sea sólo tu voz, mi niña.

Aunque sea tu foto o un dibujo a medio hacer.

Aunque sea tu risa tu adiós o tu reclamo.

Aunque sea tu irte despacio a la escuela y mi tristeza más honda.

Aunque sólo sea no importa.

Me llenás el espacio y aparecen las constelaciones

a pleno mediodía

y lloro en silencio

mi dicha

aunque sea que te tenga

lejana

y distante.

7 de mayo de 1989 
II

¿En que universos andás

niña mía

cuando estás dormida?

Contemplo

tu carita morena

reposando

flotando en el sueño

y me digo:

mi niña viaja ahora

por nebulosas lejanas,

se para

a comprar frutas

en planetas

que visitó El Principito.

Ríe

quizás con muñecas

que le salen al paso

y la invitan a tomar el té

en sus tacitas

de china o de peltre.

Mi niña está ausente

distante

porque hay años luz

en los sueños

de un niño.

“-Papi estás ahí?

¡No te vayás!

Quedáte conmigo

dormido..."

Y mi niña sigue viajando

en su sueño

flotando

como una pequeña astronauta

y yo

contemplando

siguiéndole el curso 
sabiendo que habrá de volver

cuando se despierte

porque va atada a mí

fuertemente

con las amarras

del alma.

6 de Mayo de 1990

III

Sé que estás dormida

en tu casa

mi nin̄a

Ursulita

mientras yo aquí

junto a mi máquina de escribir

trabajo en un artículo

sobre Roque Dalton.

Me detengo un momento

y pienso

y divago.

Mi corazón navegante

despliega sus velas

$y$ te visita en silencio.

Buenas noches, mi niña.

Te beso en la frente

te arropo

y retoma mi corazón marinero

a la playa

a la isla

al lugar donde fabrico

mi red de palabras

para seguir apresando

ilusiones

y sueños.

Buenas noches,

mi niña.

Desde lejos

desde este mi faro 
mi corazón atento

vigila

y acompaña tu sueño.

23 de Agosto de 1991

IV

A William Alejandro

Hijo

te me fuiste

sin apenas conocerte.

Dicen que eras mi vivo retrato:

la nariz grande

la barbilla

los ojos vivaces

y la frente amplia, muy amplia.

Viniste a la vida

por sólo tres meses

y te asomaste apenas

a su pequeña ventana.

¿Qué te llevás de recuerdos,

mi niño?

¿Qué miraste?

¿Qué imágenes se grabaron en tus ojos de ángel, en tu mente?

¿Qué irás a contar

a tus compañeritos de estancia

cuando te pregunten:

y cómo era eso,

cómo es ese lugar donde dicen que hay guerra

miseria

y llanto?

¿Es verdad o mentira

que allá sólo se sufre

y que es preferible este limbo

donde no hay padres ni madres

pero tampoco se padece sed ni frío? 


\author{
Te me fuiste yendo \\ mi niño \\ lentamente. \\ No sé qué pensaste de mí \\ porque de tu mamá \\ ciertamente \\ conociste su afecto. \\ La redondez y lo dulce \\ se imprimió en tus deditos \\ $y$ en tu boca sedienta \\ de leche y de mimos.
}

No sé si me viste

entre sueños

mi niño.

No sé si en los labios de tu madre

alguna vez

escuchaste mi nombre.

Pero cuando te marchaste

cuando decidiste partir

como El Principito

hacia planetas y estrellas

de un cosmos lejano

parte de mí

se puso en movimiento

empezó a viajar

a flotar

con la inagravidez del astronauta

en pleno vuelo

con la pericia con que echan al vuelo

y planean su amor

los amantes.

Cada noche

cuando llevo la vista

y mi ilusión camina

entre luceros

y nubes

y silencios

voy detrás de ti

hijo mío.

Esperame.

Un día de estos 
en alguna estrella

te alcanzo.

25 de marzo de 1992

Aunque los poemas dedicados a Ursula no hayan sido compuestos en la Arboleda porque yo no vivía ahí por esos días - padecía el exilio-, sin embargo, los traigo a cuento porque a veces recito de memoria alguna de sus partes mientras mi hija duerme y yo ando por ahí regando viendo mis plantas durante la noche: Ursula es ya una muchacha de 18 años, pero igual me suscita una infinita ternura, como cuando era una niña de ocho o nueve años.

Como los poemas anteriores dedicados a Ursula, en el poema dedicado a mi hijo muerto se expresa una enorme nostalgia y tristeza. Me doy cuenta ahora de que la separación, el exilio respecto a la Arboleda acentuaban la natural tristeza por la separación y aun la muerte del hijo. Ahora, el contacto más directo con mis árboles y las plantas, ha atenuado la tristeza y ésta me ha ido transformando en algo así como en una nostalgia cósmica, sobre la cual volveré en otra ocasión, pero, en todo caso, un sentimiento más optimista y más cercano a eso que estamos definiendo como ternura.

En cuanto al sentimiento o persuasión de seguridad mía y de mis allegados, tengo alguna anécdota que contar y varias reflexiones que hacer... Hace un par de años, Luisa me dijo, en el transcurso de una conversación, que ella prácticamente me veneraba con un santo y que, en ciertos momentos, pensaba en mí para pedirme mentalmente algún favor. “- ¡Hasta te he soñado caminando sobre las aguas del mar...!", concluyó riéndose divertida.

Lo curioso del caso fue que también por esos mismos días a mí me había ocurrido algo parecido, respecto de ella y de otras personas cercanas a mí. “Yo le pido mentalmente a mis hijos, a Luisa (!!!) para que me den fuerzas y así poder salir avante en los grandes y pequeños problemas de cada día. Porque, del mismo modo que le ruego y oro a mi papá (ya muerto), a mis antepasados y a Ellacuría \& Cía, así también lo puedo hacer con personas aún vivas".

Asombrados, comentamos Luisa y yo esa suerte de telepatía, a través de la cual nos comunicamos algunas veces ideas e intuiciones y hasta sueños; también reflexionamos un poco acerca de la verdad que podía estar contenida en esa nuestra intuición de entonces: "Si amamos profundamente a alguien, eso quiere decir que esa energía positiva — y hasta lumínica, podríamos añadir-, nos invade, de modo que con sólo recordar a los hijos o a otra persona y ser amados, uno es capaz de irradiar alegría; es decir, uno puede "brillar" de contento (" $i-C o ́ m o$ te brillan los ojos cuando hablás de ella!", dicen los amigos a un hombre enamorado) y contagiar a otros con su optimismo y su contentamiento". 
En este orden de cosas continué yo reflexionando: la llamada santidad atribuida a alguna persona u otro ser (un poste totémico, por ejemplo) no sería, en último término, sino la "virtud" que tiene ese alguien venerado, de producir en nosotros sensaciones de tranquilidad espiritual y la seguridad plena de conseguir algo que anhelemos con vehemencia. "Santo", pues, es quien hace brotar de nuestro ser interior los más delicados sentimientos y emociones, a la par que permite acrecer la seguridad en nosotros mismos y en la asequibilidad de nuestros proyectos.

La aplicación de esos conceptos no paró ahí... Ahora estoy convencido de que mis árboles y plantas también tienen "virtud" y de que están formando sobre mí y los míos una especie de coraza invisible pero protectora... Sé que nunca podrán hacerme daño (el otro día, a resultas de un viento huracanado, cayó una gigantesca rama seca de un árbol de fuego; pero en un tiempo y en un lugar donde nadie corrió ningún peligro); y no sólo eso: sé perfectamente qué árboles y plantas de mi Arboleda están captando el amor y la dedicación con que me entrego a ellos. Yo percibo a cada momento su agradecimiento, bajo la forma de una hermosa flor que acaba de brotar o de un aroma que me sorprende pronto. Es como si me dijeran: “- ¡Schiittt... fíjate en esa florcita... olé aquel aroma...! ¡Contemplá lo hermosas que lucimos ahora para vos!”

Por eso, yo les pido a mis plantas que me protejan a mis hijos; que los defiendan de todo mal. Ellas son, pues, como "la magnífica" que llevan en su cartera ciertos devotos creyentes; o como la piedra del rayo, extraída a base de agilidad y valor de una culebra zumbadora y que vuelve prácticamente invulnerable a quien la porta; o, en todo caso, equivale la protección de mi Arboleda a un buen baño de agua de ruda, esa planta tan olorosa que espanta las enfermedades y los malos duendes... En suma, en estos últimos meses creo que he sellado, casi con un pacto, mi "devoción” por las plantas y seres animados e inanimados de mi Arboleda. Y "devoción” no sólo en el sentido de dedicación fiel a su cuido, sino en el sentido de "fe" en ellas... Soy un devoto ferviente de la santería de lianas, bejucos, piedras y seres entre reales y totalmente imaginarios que constituyen mi Arboleda...

Hay algo que yo no domino todavía; esto es, la repercusión que tienen en mí las salidas noctumas de mis hijos, Arcadio y Ursula. Cuando alguno de ellos se tarda durante la noche o madrugada más de la hora prevista, entonces entro en una dinámica de ansiedad que no para fácilmente... No duermo y me dedico a dar vueltas y vueltas, como si fuera león enjaulado; porque comienzo a imaginarme lo peor que puede estarles pasando... Claro, en un país con tan alto índice de criminalidad, todo puede ocurrir. Arcadio, sin embargo, me insiste en que he de confiar en ellos: ya saben cuidarse y, además uno no puede estar piensa y piensa en que algo malo ha de ocurrir, porque entonces uno sí puede estar "llamando" la desgracia... Yo sé que debo aprender a "soltar" a mis hijos; asu- 
mir que su realización personal pasa por el riesgo de que algo grave les advenga a lo largo de sus andanzas...

Hace unos'meses, Arcadio compró una moto pandillera que, aunque viejita, todavía tiene buena estampa. Es su niña bonita: pasa horas enteras limpiándola, reparándola o simplemente contemplándola. Yo le advierto continuamente acerca del peligro. “--Pero, papá, no tenés que preocuparte; yo soy prudente y siempre manejo despacio... ahora, si algo ha de pasarme, pues qué le voy a hacer...!"

Un día de estos me dijo: “-Fíjate que acabo de ver un programa de la tele cómo dos vulcanólogos japoneses eran arrastrados por la lava, cuando examinaban un volcán en erupción; el miembro del grupo que se salvó, pudo filmar la muerte de sus colegas... ¡Qué chivo: ellos murieron en aras de su profesión... haciendo lo que les gustaba!"

El imaginarme que algo puede pasarles a mis hijos no es fundamentalmente una manifestación paranoica —aunque algo de eso haya-; es un temor bien fundado. Pero aun así, debo soltarlos... debo aprender a dejarlos en libertad, no sólo en cuanto a su comportamiento y dosificación de sus responsabilidades y tiempo libre - lo cual yo hago bastante bien-, sino en cuanto a tiempo y espacio psíquicos. Porque uno puede acaparar o copar a alguien con el pensamiento... “-Fíjate que yo no me siento a gusto en una fiesta si sé que vos, papá, estás pasando angustias -me dice Ursula-. Ni vos ni yo estamos tranquilos, porque siento que estás allá a lo lejos como observándome nervioso, agitado..."

Soltar a los hijos, dejarlos que vuelen implica, pues, liberarlos de una tutela demasiado pegajosa y absorbente, aun en el terreno de lo mental. $Y$ eso es algo que se dice muy pronto y que puede captarse con cierta facilidad en teoría; pero cuando se trata de ponerlo en práctica... cuesta enormemente. "-Es casi como "matar" a los hijos - me decía el amigo Herman Rosa-, porque así como en un tiempo uno tiene que convertirse en "parricida" y en "matricida", en cuanto debe 'matar' la independencia respecto a los padres; ser "filiocida" y "matar" la también dependencia enfermiza que se puede mantener con los hijos".

Pero yo creo que, más bien, uno es el que debe "morir" a los hijos... Cuando yo me liberé de la dependencia malsana que caracterizaba mi relación con las mujeres, me sentí "resucitado". Porque para llegar al estado de liberación, yo debí pasar por un trance de muerte, y esto de modo casi literal. Fue una prueba de iniciación en la que tuve el "acompañamiento" de Luisa; fue tan parecida a esos "pasajes de tránsito" a que son sometidos hombres y mujeres, en el seno de algunas culturas mal llamadas primitivas. Para pasar de la infancia a la adolescencia, y de esta a la adultez, hay pruebas sumamente severas; la película "Un hombre llamado Caballo" da cuenta de esas bárbaras pruebas a que eran sometidos los jóvenes que querían ganar su estatus de guerreros: les perforaban la piel 
del pecho con unos palos; así debían danzar horas y horas, hasta que la piel se rompía y los jóvenes caían exhaustos.

En esos "pasajes de tránsito" se experimenta un dolor o una depresión tan intensa que uno cree morir. Y ésa es la idea: pasar de una etapa a otra en la vida equivale a hacer morir la vieja piel, despojarse de la vestidura roída y caduca, para estrenar después un traje - alma y cuerpo- nuevo. Por eso, la culebra, que cambia de piel fue venerada por nuestros ante pasados precolombinos como símbolo sagrado de todas las renovaciones naturales y humanas.

Uno de los arriates de mi jardín está dedicado al Xipe-Totec: el dios que cambia de piel, como cambia la piel la madre naturaleza cuando se cubre de una nueva cubierta vegetal al comienzo de la época de lluvias. Mi Xipe-Totec es un ídolo de piedra, feo y deforme como casi todos los dioses precolombinos; pero para mí tiene un alto valor simbólico: está casi completamente cubierto de musgo verde y afelpado, fresco y brilloso. Él representa vívidamente la renovación constante que yo quiero para mí y para las personas que amo. Es el dios que preside mi Arboleda... Por él estoy aprendiendo a dejar que mis hijos se enrolen en sus personales e intransferibles cadenas de transformaciones ... Habré pasado la prueba cuando comprenda íntegramente - con el cerebro y con el corazónque mis hijos tiene derecho a elegir el rumbo de sus vidas, y hasta el rumbo de sus muertes... ¡Que el Xipe-Totec me instruya! ¡Que mi santa Arboleda me colme de docta sabiduría par aceptar con naturalidad ese trenzado maravilloso de la vida y de la muerte, aunque eso signifique en algún momento la pérdida de alguno de mis seres queridos!

Mi hijo Arcadio - Cayo, como le decimos- es muy tranquilo en eso de ponerle buena cara a lo que venga. Ya conté en otra parte cómo se libró de morir en el accidente de Aviateca, en 1995. Pues bien, al cumplirse un año de la tragedia aérea, mi hijo viajó al volcán Chinchontepec, San Vicente, al lugar mismo de los hechos. Me cuenta Cayo que — todavía se veían restos del avión por todas partes... El tomó una bandeja para servir comida, un plástico de una ventanilla y una pequeña lámina donde iba la salida del aire acondicionado y la luz correspondientes a cada uno de los asientos... Los guarda aún como reliquias. Pero, además, trajo una bromelia (gallito) que, al poco tiempo de llegar a la casa, dio una flor roja muy hermosa... Para Cayo, el viaje ése fue una especie de ex-voto: reconocimiento agradecido de que él pudo haber muerto ahí y de que a saber por qué designios no le tocó entonces. La bromelia, amarrada ahora a un árbol, es un silencioso recordatorio para Cayo y para todos nosotros en la Arboleda.

\section{Conservando el patrimonio axiológico y natural}

Mi papá cuidaba su jardín día con día; tenía también varias cosas que constituían algo así como un tesoro: el retrato de la abuela con alguno de sus nietos, el 
primer trompo que tuvo cuando cipote, una campanita de bronce, varios libros empastados; pero, ante todo, su colección de figuras para el "nacimiento" de las fiestas navideñas: alrededor de cien, de varios tamaños: desde unas grandes de unos $60 \mathrm{~cm}$, hasta otras pequeñitas, de apenas $5 \mathrm{~cm} \ldots$

Sin embargo, al morir mi papá en 1989, comenzó el deterioro de su tesoro: el jardín fue descuidado, hasta el punto que se perdieron algunas plantas, y el aspecto general ya no es ni la sombra de su mejor época. En cuanto a los objetos, han ido desapareciendo o deteriorándose. Quizás los que han tenido mejor suerte han sido las figuras del "nacimiento": están prácticamente todas en buen estado; pero tampoco ellas reciben ahora la atención esmerada que les prodigaba mi papá: apenas si salen algunas de ellas a lucirse cuando es diciembre la familia arma un remedo de "nacimiento" (comparado con el monumental que acostumbraba hacer mi papá). En suma, eso que constituía la posesión más querida de mi padre ¡su patrimonio! ha ido cayendo en el olvido porque nosotros sus hijos y depositarios de su herencia, no fuimos capaces de tomar como propias esas responsabilidades. Y esto, a pesar de que todos veneramos la memoria de nuestro padre, y de que intentamos emularlo en muchas cosas: su amor inclaudicable por los suyos, su honestidad a toda prueba, su dedicación al arte y a la poesía, y el cultivo y conservación de las plantas.

¿Paradójico, no? Teniendo tanto en común con mi padre, ¡No pude ser un verdadero continuador de sus aficiones y devociones!... Pero, por ahí creo que viene la cosa: la estima que mi papá le tenía a ciertos objetos, actividades, personas y lugares, ya no puedo tenerla yo con la misma intensidad, por más que me empeñe en ser fiel a su memoria. Y esto es lógico: mis focos de atención y de interés están puestos en otros objetos, lugares y personas. Pienso que sigo siendo fiel a los valores fundamentales que me inculcaron mis progenitores, en la medida en que trato de plasmarlos y hacerlos vida en lugares, personas y objetos que a mí, en lo particular, me llaman la atención... Así, el amor al arte y a la poesía que heredé de mi padre tiene otras concreciones distintas suyas: me gusta otra música (a él le encantaban las baladas de Agustín Lara) y leo otros libros de poesía (sus predilectos eran Amado Nervo, Juan Ramón Jiménez, Rubén Darío).

Mi pasión por la jardinería también a él se la debo, aunque mi "pila" sea ya no el jardín que él cuidaba, sino la Arboleda de Antiguo Cuscatlán... En resumidas cuentas, el patrimonio y la herencia dejada por nuestros padres a nosotros sus hijos, hace referencia, más que a objetos y lugares concretos, a un conjunto de valoraciones acerca de las personas, lugares y cosas. Estas valoraciones $\longrightarrow$ valores, algo que suena más enfático- podrán aplicarse y hacerse realidad concreta en escenarios diferentes a aquellos en los cuales transcurrieron las actividades y aficiones de nuestros padres. Por todo lo cual, puedo decir con bastante seguridad que en mí se continúa el espíritu de mi padre, porque soy fiel a los grandes valores que alentaron su vida. Participo, pues, de su mismo aliento vital. 
Sin embargo, creo que en estos momentos las cosas han cambiado un tanto para nuestro grupo familiar; de modo que patrimonio sí tiene que ver mucho con la materialdad: la Arboleda de Antiguo Cuscatlán sólo será de Arcadio y de Ursula (no como en el caso de mi papá, cuyo patrimonio quedó como algo indiferenciado respecto a nosotros sus hijos), en ese orden de cosas, me preocupaba hace unos meses el que Cayo no acabara de responsabilizarse de ciertas tareas domésticas. "-Hijo, ¿porqué no mantenés limpia esta terraza que da a tu apartamento? Si yo no hubiera sembrado plantas en este arriate, ino creés que seguiría la pura tierra, como antes estaba? ¡Y eso que está al ladito tuyo!"

Pero mi hijo ha asumido estas tareas: hace poco limpió el techo del apartamento y tapó la gotera que le mojaba la ropa y los libros. Yo le insisto: "-Si vos no tomás esto como cosa tuya, pues puede llegar un día que se aparezca una compañera o esposa tuya, que decida botar los árboles y encementarlo todo..." “- ¡No, papá, eso no va pasar; no te preocupés!".

"Como a ellos no les costó nada ni la casa ni el terreno como ellos no tienen que pagar comida, luz o agua; por eso es que no asumen como propias tareas y responsabilidades de la casa... Y esperan que esté papi o mami para solucionarles los problemas". Esta es la etiqueta que uno estaría tentado a ponerle a la desidia y apatía de los hijos... Pero la clave para que eso no se convierta en una triste realidad está en lograr que ellos vayan asumiendo, en la práctica, un fuerte sentido de pertenencia... A base de pláticas con Cayo y Ursula; pero, sobre todo, a base de hacer cosas juntos, vamos logrando que se fortalezca ese interés por la casa y su entomo...

Con Cayo cortamos cada mes, más o menos, la grama San Agustín del arriate de la calle; nos ponemos, con ladrillos y cemento, a construir arriates alrededor de los árboles; barremos el terreno de vez en cuando, y procuramos ayudarnos en todas las tareas domésticas, cuando no llega la empleada.

¡Sentido de pertenencia: esta es Mi casa, Mi terreno, y de Mi dependen que estén limpios y dé gusto estar ahí...! ¡Pero también yo pertenezco a ellos: soy una pieza clave en el funcionamiento y en la vida de este hábitat! Pues bien, hagamos ahora una extrapolación a lo que está ocurriendo aquí en El Salvador...

Hace unos meses apareció el documento "Bases para elaborar un Plan de Nación". Discutible en cuanto a sus fundamentos ideológicos y propósitos reales, pero el documento es loable, sin embargo, en cuanto al espíritu que aparece alentarlo: lograr que todos los salvadoreños se pongan a pensar sobre su país; que se reúnan a debatir acerca de qué país quieren para sus hijos y descendientes. El documento apela, pues, a lo que debería ser una preocupación básica de todos: el tomar como propio el destino nacional... Hoy por hoy, no existe esa preocupación... por múltiples razones históricas que no podemos examinar aquí. Pero, lo cierto es que uno de los problemas que nos agobia es de raíz actitudinal: 
los salvadoreños no tienen verdadero sentido de pertenencia, a pesar de todas las proclamas nostálgicas y sentimentaloides de quienes, estando fuera, añoran el sabor de las puppsas o del chilate con núegados...

Porque no es casualidad el que tantos y tantos miles de salvadoreños quieran irse a los E.U. a probar mejor suerte. ;Ah, es que se piensan ir para mandar ayuda a sus familiares; además, no más puedan se regresan al terruño...! barata; el hecho es que aquí en el país te sentís como de paso ja ti qué te va importar que la basura se amontone formando volcanes en las calles, barrios y aun en ciudades! (si algo llama la atención a los extranjeros es esa suciedad que se respira por todas partes en El Salvador) ¡En qué te puede afectar que se estén acabando los bosques de bálsamo y venados cola blanca! (¿Con qué se come eso?).

La fuente primera de la degeneración de valores - dice, más o menos el documento en cuestión- es la familia: A algunos, esto les suena tradicional y romántico, porque si hay algo que no funcione en la sociedad globalizada eso es la familia... Sin embargo, yo creo que aquella afirmación contiene gran parte de verdad: Si yo voy adiestrando a mis hijos a que asuman responsabilidades y un patrimonio más amplio... "-Así como cuidás tu casa, tu heredad familiar, de la misma manera debés cuidar el país donde habitás, porque él es también tu casa, tu hogar: ahí pertenecés. Sus recursos naturales, su historia y sus gentes constituyen también TU patrimonio... Recordemos que PATRIA y PATRImonio son palabras afines, viene de la misma raíz..."

Ahora bien, si en el seno del hogar no se facilita, a los jóvenes (y a viejos) dar el paso desde la experiencia del hogar, entonces muy poco tienen que hacer leyes y decretos. Y entonces, también, el cambio de actitudes habrá de lograrse por la vía de la compulsión y aun de la represión. Es bien sabido que los salvadoreños tienden a funcionar bien sólo cuando pende sobre ellos un castigo. Por ejemplo, para todo el mundo es evidente que usar el cinturón de seguridad en los asientos de adelante de un automóvil es una necesidad de vida o muerte... Y, sin embargo, esa práctica sólo ha comenzado a ser verdaderamente aceptada a partir de las multas que pone la policía a los infractores. Aun entonces, el salvadoreño "vivo" intenta la "zafada": los motoristas de microbuses sólo llevan medio puesto el cinturón y están prestos a deshacerse de él al no más desaparecer la amenaza policial. Además, muchos ciudadanos refunfuñan por la medida al abordar un auto y quizás terminan cumpliéndola sólo por evitar "mayores males": la multa o la reprimenda...

Sin embargo, así, a base de temor, los salvadoreños pueden ir intemalizando conductas y actitudes nuevas, y quién quita si después de dos o tres generaciones ya sea un hábito entre los salvadoreños el ponerse el cinturón al abordar un auto: una acción tan mecanizada como cambiar de velocidades o sacar el brazo al doblar una esquina... De la misma manera podría lograrse el hábito de la 
limpieza o del respeto a los recursos naturales y al patrimonio histórico o arquitectónico. Porque quizás a base de palos los salvadoreños lleguen a desarrollar algún día un fuerte sentido de pertenencia y se atrevan a defender como suyos edificios que representan algún valor histórico o arquitectónico, o especies animales y vegetales en peligro de extinción.

Mientras tanto, la impunidad con que operan los destructores del país es alamante; impunidad derivada no sólo de una "conciencia" ciudadana muy hábilmente troquelada. Porque se le ha hecho creer al salvadoreño que el "progreso" significa deshacerse de todo lo viejo e inútil; y dentro de esa óptica, una zona arbolada es un "desperdicio" que puede subsanarse construyendo un centro comercial, o un edificio antiguo es un "vejestorio" inútil que bien puede reemplazarse por una flamante gasolinera. $\mathrm{Y}$ esto que estoy diciendo no es pura invención o alegoría piadosa; de manera altamente simbólica una calle de San Salvador llamada "El Progreso" acabó por retacear y hacer parche una hermosa casa situada entre la $49 \mathrm{Av}$. Norte y la Alameda Roosevelt —según cuentan, dotada con mobiliario traído de Francia - acabó por dejar espacio a una gigantesca gasolinera "Chevron". Otra casita ubicada en el mismo terreno, aún dejaba ver hasta hace pocos meses unas hermosas vigas de madera tomeadas; pero la furia destructora no se sació hasta ver el lugar de la casita una ancha calle asfaltada...

El más doloroso símbolo está en los alrededores de Metrosur, ahí, paralela a la Alameda Juan Pablo II corría una barranca, poblada de árboles, pero también vertedero de basura para una colonia aledaña. El hecho es que en uno de los márgenes de la barranca funcionaba un vivero de nombre "Xochicali" ("La Casa de Las Flores") y la fotografía toda se prestaba para haber mantenido un pulmón en la zona y un santuario para algunos animales. Pero el "progreso" se impuso y hoy tenemos en lugar de la barranca un gigantesco parqueo asfaltado que, para colmo de males, siempre está trágicamente vacío. El salvadoreño prefirió ese inútil y achicharrante parqueo a un "Xochicali" o casa de Las Flores.

En varias ocasiones he sostenido que los salvadoreños se van pareciendo cada vez más a los fenicios (la idea no es mía: ya Hugo Lindo la acuña en uno de sus ensayos de su obra Recuento). En esta oportunidad voy a abundar un tanto sobre esa idea, con el fin de aclararme un poco más eso de la "conciencia" del salvadoreño... Interesados en el dinero fácil (“¡Bisness!” “¡Bisness!”) los salvadoreños son capaces de vender a su madre o a su hijo... Recuerdo una cantinela que oía cuando era niño:

"Chico Perico mató a su mujer,

hizo tamales para su vender.

No compren señores, no compren señores,

Que son de mujer". 
“- ¡Ese es el retrato del salvadoreño "animala": no se tienta los hígados para hacer un poco de plata, así lleve de encuentro a alguno de su familia!". Eso dije una vez en clase, "-Tan exagerado que sos, Lito. Es tu odio a los guanacos lo que te lleva a decir esas cosas...”, me replicó alguno de los alumnos. ¡Cúal sería la sorpresa de todos cuando por esos mismos días salió en el diario que habían descubierto y apresado a una banda de vende niños... entre los traficantes estaba una señora que había vendido ya a su propio nieto! "-¡Ahí está la prueba: qué más quieren!", repliqué de nuevo a mis alumnos...

Los fenicios eran famosos en la Antigüedad por ser hábiles navegantes y comerciantes. Sus barcos recorrían de cabo a rabo el mediterráneo; dieron la vuelta a África y hasta se dice que llegaron a América... Comerciaban con todo: metales, armas, cereales y hasta personas, a las que compraban o vendían como esclavos. Era famosa, en este sentido, la cautela de quienes se atrevían a viajar como pasajeros en los barcos fenicios. Pagaban el pasaje y suponía que serían llevados a su más o menos lejano puerto de destino; pero podía ocurrir que en algún puerto donde hicieran parada, alguien requiriera esclavos; y, entonces, los fenicios no tenían reparo en vender a sus mismos pasajeros, para que fueran esclavizados... Te dormías siendo libre y te despertabas encadenado en el camino a alguna factoría. ¡Ese era el riesgo de confiar en los fenicios!

La actitud de los fenicios ante la cultura contrastaba con la actitud de los griegos... Griegos y fenicios vivieron durante casi la misma época: siglos $\mathrm{X}$ al III a.C.; unos y otros fueron muy hábiles mercaderes (la época del máximo esplendor clásico tiene la base en el imperialismo mercantil ateniense); pero, mientras los fenicios tuvieron una visión cortoplacista y chata sobre la cultura, los griegos la tuvieron de larguísimo y aun de indefinido alcance. De los dioses fenicios poco recordamos: Astarté, Baal o Moloc; y, más bien, resalta el aspecto monstruoso de alguno de ellos, frente al refinamiento en la concepción de dioses griegos como Afrodita, Atenea o Febo... Pero, lo más sobresaliente de todo fue que los griegos parecieron comprender que su "inversión" en la cultura los eternizaría, y que la bonanza económica debía convertirse necesariamente en edificios como el Partenón, o en esculturas como Discóbolo de Mirón, o en tragedias como Edipo rey, de Sófocles.

No es mera casualidad que de la antigua Fenicia hayan venido muchos de nuestros financistas, ahora salvadoreños de tomo y lomo... Pero, veamos algún ejemplo en que reluce la típica actitud fenicia en el actual El Salvador... Si algo llamaba la atención de la casa donde estuvo una vez la Odeca, ahí sobre el Paseo General Escalón, era su belleza arquitetónica, pero también su entomo: gramales y árboles completaban la belleza de la mansión, ubicada estratégicamente en una zona elevada... Gran parte del encanto de la casa consistía en que podía verse desde varios ángulos, y en todos resaltaba algún detalle de la casa misma o de los jardines. ¡Como el Partenón, que puede verse desde abajo en casi toda Ate- 
nas! ¡Su majestuosidad depende no sólo de la belleza misma de la edificación, sino de la altura y elevación en que está! ¡No entender eso es ser un filisteo, un fenicio de la cultura!

Pues así como pudieron haber hecho los fenicios con el Partenón (levantar un mamotreto gigantesco para "conservarlo" y ocultarlo a las miradas de los atenienses) si los hubieran dejado, así hicieron nuestros fenicios criollos: levantaron una pesada y lisa y chata mole de cemento en lo que antes fueron los maravillosos jardines de la ODECA, y envasaron la casa... ¡Pobre: ahora da la sensación de casa embalsamada, de quetzal sustraído de su entomo, asesinado y, para colmo de males, mal disecado...! ¡Qué bien por los taxidermistas de nuestra cultura!

Otra de las características de la "conciencia" del salvadoreño, conectada con las anteriormente vistas, es la propensión a creer en mitos como: "el salvadoreño emprendedor, no se achica ante nada", o "el salvadoreño es el judío o el taiwanés de Centroamérica". Pero yo creo que lo más grave de todo es que estamos ante una verdadera mitomanía... El mitómano es aquel que a fuerza de tanto decir y decirse mentiras, se las llega a creer él mismo. Hace unos años hubo en la UCA un profesor muy peculiar: cada cierto tiempo se ausentaba durante unos días, y no daba sus clases habituales. Al aparecer de nuevo, contaba a sus alumnos que había estado en Venezuela diseñando, primero, y ayudando a construir, después, unos importantes oleoductos. La admiración era general, hasta que un día se supo que todo era una mentira: él permanecía encerrado en su casa, haciendo creer a todos que estaba de viaje. Lo curioso era que el tal profesor hasta hablaba como venezolano, sobre todo, durante los días en que acababa de "regresar" de Venezuela. "- ¡Vale, Chico...!", repetía a cada rato... Después de un tiempo, nuestro pobre mitómano acabó mal, porque se descubrieron algunas de sus mentiras gruesas - había comprado fraudulentamente un título universitario-, y ahora anda huyendo a saber por qué países porque pesa sobre él una orden de captura.

Pero el caso no constituye una rarísima excepción. Quien más, quien menos, los salvadoreños son presa de la mitomanía: se embeben en ficticias grandezas... Desde tiempo inmemorial, por ejemplo, se viene cargando con una mediocre selección de fútbol; pero el milagro se repite cada cuatro años, porque es entonces que renace la certeza de que se irá de nuevo al campeonato mundial de fútbol y que ahí se le ganará a medio mundo. Y cada cuatro años, la realidad se encarga de poner en evidencia los engaños: o goleadas monumentales de 10 a 1 , o quedarse en la antesala, humillados hasta por equipos que no tienen una sólida tradición futbolística.

Lo que acaba de pasar en los juegos Centroamericanos y del Caribe es otra muestra. El Salvador ocupó un $9^{\circ}$ lugar entre veintitantos países. Subió, pues, de los últimos lugares que simpre ocupaba, a un lugar un poco más decente. A ello 
contribuyeron varios factores: mayor interés por invertir en los deportes, por parte del gobiemo y la empresa privada, presencia de entrenadores cubanos, etc., etc. Pero ese "sako de calidad" se ha publicitado por activa y por pasiva... Corrió dinero para los atletas medallistas, y a todos los deportistas y entrenadores se les celebró prácticamente como a héroes, con cobertura en todos los medios.

En principio, eso está bien como un estímulo inicial al repunte del deporte en el país; pero de eso a saludar los resultados como auténtico triunfo, es engañarse vilmente. Porque, en último término, El Salvador lo que ha hecho es pasar de ser malo y pésimo a ser mediocre. La celebración con bombo y platillo podría hacerse cuando el país se le ponga enfrente, de tú a tú, a países como Cuba o México. Pero lo de ahora ha sido inflar lo poco que se tiene, queriendo hacer creer a todo el mundo que se ha dado un verdadero "salto de altura", cuando todos sabemos que apenas empezamos a caminar sin andadera.

Alimentando esa falta conciencia de sí es como algunos listos hacen de las suyas, engañando a otros más "listos" o dispuestos a dejarse engañar. "Hacerle a uno la mejicana" quiere decir que alguien puede entuturutar a un cristiano con sólo hablarle y hablarle. Así, el truco consiste en "cambiarle" a uno un billete de a cien, por ejemplo, por únicamente diez billetes de a cinco colones o de menos. Los afectados dicen que el pícaro "como que los hipnotizó": “- ¡Ni sentí cuando le di el billete!". Pero "la mejicanada" es un eufemismo para llamar a lo que, en el fondo, es simple y llana estafa a "la salvadoreña". Si no, ahí están las millonarias estafas de INSEPRO y otras más para probarlo...

Además otro mito: "El salvadoreño odia sin cuartel al mexicano. En última instancia, lo que ocurre es que el salvadoreño proyecta en -otro (parecidísimo racial y culturalmente a él), el odio que se tiene a sí mismo. Por un curiosísimo juego de espejos, se da ese autocastigo y autorechazo: otra broma que le juega la realidad al mitómano salvadoreño. Porque si en algo se ve realizado el salvadoreño de estratos bajos y aun medios y altos, es en películas y en canciones mexicanas... ese mismo espacio ficticio "chabacán" y bajero (aunque no sólo eso, claro) identifica a los salvadoreños con los "odiados" mexicanos.

Pero, dejemos ya de acumular pestes sobre nuestros paisanos y veamos, más bien, si hay esperanzas para salir de este hoyo negro... Ya lo dijimos antes: sin acciones drásticas, punitivas y bien planificadas, el país irá retrocediendo aceleradamente, por más que se ideen fachadas y maquillajes al estilo de megacentros comerciales y pasos a tres niveles en supercarreteras... mientras no se enfrenten problemas cruciales como el crecimiento poblacional (dejando atrás reaccionarismo eclesiales), el deterioro ambiental, el empobrecimiento acelerado de las grandes mayorías, lo demás son puros paños tibios...

Y aquí queremos señalar la contraparte de la "conciencia" (que resulta ser inconciencia) del salvadoreño. Se trata de la ausencia de un verdadero proyecto 
de nación para El Salvador. La aparición misma del documento "Bases para un Plan de Nación" implica un tácito reconocimiento de que ese plan aún no existe. Todavía se está en los preámbulos: el tratar de convencer a todos de que es necesario y urgente tener un plan... $Y$ si no surge ese convencimiento, pues entonces nadie se lanzará a contribuir a su elaboración. $O$ si alguien lo elabora, no habrá el más mínimo interés en acogerlo.

La no existencia de un proyecto actual de nación es notoria a todas luces: se invierte aquí y allá en carreteras, en construcción de más y más viviendas (los suburbios del Gran El Salvador se parecen ya a colmenas o a termiteros, con miles y miles de casas como celdas), en la elaboración de costosos libros sobre el país, y aun en la preservación de algunos recursos naturales. Pero como eso no responde a un plan macro, según el cual se hayan establecido prioridades, entonces, lo que se pone son parches: se salva un poco de montaña por aquí, se hace un descomunal centro comercial por allá; pero todos son microproyectos puntuales, descoordinados. De manera que tenemos aberraciones como las siguientes: se están expandiendo las urbanizaciones sobre las zonas que, precisamente, deberían ser conservadas con su cubierta vegetal, para asegurar el recurso agua, cada vez más escaso a medida que aumentan las mismas urbanizaciones... Contrasentidos y absurdos como éste sólo son explicables en un país donde el "progreso" avanza desordenadamente, canibalizándolo todo, naturaleza y seres humanos.

De todo lo anterior podemos sacar en claro que estamos amarrados en un círculo vicioso: no se genera una auténtica conciencia ciudadana porque no existen verdaderas prácticas participativas; y no hay participación, porque no se tiene conciencia de su urgencia y de su efectividad. ¿Estamos, entonces, en medio de un remolino y de un vértice que nos consumirá a todos? ¿Hay alguna salida todavía, o estamos más bien ante un país que ya no es viable bajo ningún punto de vista?

\section{La propuesta de Horacio: su retiro a la quinta de la Sabina}

A Quinto Horacio Flaco (65-8 a.C.), conocido como Horacio, le ocurrió algo que puede ser tomado como modelo o arquetipo de salida ante una crisis de civilización; revisemos, entonces, la aventura de nuestro poeta romano. Clinio Mecenas (69-8 a.C.) era ministro y amigo personal del emperador César Augusto (63 a.C.-14 d.C.); debido a su afición por el arte y la literatura, Mecenas aprovechaba su amistad con el César y su enorme fortuna personal, para favorecer a artistas y literatos que mostraban talento; entre ellos estaban: Virgilio, Tito Livio, Salustio, Propercio, Ovidio y nuestro amigo Horacio. El favor de Mecenas se mostraba de múltiples maneras: ayuda económica, invitación a formar parte de su círculo de amigos e íntimos, asistentes a sus fiestas y reuniones. Pero Mecenas se excedió en su favoritismo con respecto a Horacio: un día le regaló 
una quinta ubicada en los montes Sabinos - la quinta de la sabina. Para el protector de Horacio esto resultó contraproducente, porque en lugar de tener más tiempo a Horaciołjunto a sí, lo comenzó a ver con menos frecuencia. Resulta que el poeta prefería retirarse a su quinta, huyendo del bullicio de Roma. El agravante para Mecenas fue el deterioro de su salud que por entonces empezó a sufrir: durante los últimos años de su vida padeció de una enfermedad rara: le aquejaban continuas fiebres y no podía dormir ni de día ni de noche. Desesperado, Mecenas tomaba varias pócimas: tés, vinos... pero, lo más que hacían los bebedizos era adormecerlo. En esas circunstancias, la presencia de amigos, poetas y cantores era perentoria para distraer al enfermo; por eso, incomodaban a Mecenas las largas ausencias de Horacio.

Pero a nuestro poeta no le importaron esos reclamos de su protector, y se entregó por completo a su experiencia ejemplar. La quinta de la Sabina se convirtió en una especie de laboratorio de donde salieron varios productos que nos pueden servir para encontrar salidas y soluciones a problemas existenciales, tanto a nivel individual como a nivel social... trataré ahora de recapitular la esencia de la experiencia horaciana.

Primero, se trata de un retiro que no implica una huida de la realidad. Horacio estaba al tanto, y muy conmocionado, por los problemas de su tiempo: la comupción de los funcionarios, la frivolidad de las costumbres y la superficialidad de las creaciones artísticas y literarias. El poeta traslada a su retiro todas esas preocupaciones, y ahi, el material en bruto es transmutado en creación literaria, en reflexión teórica. De ahí salieron muchas de sus obras: sátiras (ironias y crítica a personajes públicos), odas y épodos (alabanzas y caracterización de personas ejemplares) y epístolas (consejos sobre diversos aspectos de la vida y de la cultura; es memorable su "Epístola a los pisones" o Ars poética, algunos de cuyos principios aún tienen vigencia). La realidad en bruto, pues, es procesada en la quinta de la Sabina, hasta destilarse con ella arte y escritura.

Segundo: de lo anterior podríamos inferir que la profunda reflexión es como un elixir o licor destilado en los alambiques del alma humana. El retiro físico, el retrete, permite la escapada a los mundos interiores; de manera que ahí se puedan destilar ideas y pensamientos, así como emociones y sensaciones altamente refinados. La literatura, y sobre todo la poesía, es como el vino añejo y en su punto - sostenía Horacio en su Ars Poética - que aquella bodega puede producir. Acorde con eso, la poesía se comparte con los amigos como quien invita a sus íntimos a degustar unas copas del mejor vino.

Tercero, la base de todo lo anterior, la plataforma que permite elevarse a las sutilezas del espíritu es la aurea mediocritas. En la quinta de la Sabina se tiene lo necesario para vivir, y el poeta no es presa de la agitación por tener más y más o por la adquisición de fama y renombre (Horacio rechazó el cargo de secretario privado del Emperador). La "medianía que vale oro", tener todo en 
cantidad suficiente y no mucho más, reporta una gran paz y tranquilidad, necesarias éstas —ordinariamente- para la creación intelectual y artística. Expresión de todo eso conseguido va a ser la aequitas: la mesura, el equilibrio. El poeta intenta dar con el justo medio en todo: en la vida moral y en sus creaciones artísticas... El desborde incontrolado afea tanto una conducta (los excesos del borracho) como una obra literaria (la pérdida de la unidad del conjunto).

Extraída la quinta esencia de la experiencia Horaciana en la quinta de la Sabina, voy a intentar ahora hacer unas breves aplicaciones a mi vida personal y a la vida del país... La pequeñez del lugar, unida a su relativo aislamiento, pueden llevar a una alta concentración de energía (positiva o negativa). El lugar en cuestión se convierte en una suerte de laboratorio en el que pueden llevarse a cabo experimentos valiosísimos o, al contrario, sumamente peligrosos. Es como si un químico manipulara elementos inflamables o explosivos; dependiendo de las mezclas que sepa hacer, así encontrará la Panacea o la Piedra Filosofal, o puede volar en pedazos una casa entera.

Pues bien, en mi Arboleda he querido reproducir en alguna medida las condiciones de la quinta de la Sabina (en mis escritos anteriores ya he dado cuenta de algunos resultados). El punto es que en esos sitios privilegiados pueden producirse incluso mutaciones. Ya Horacio nos daba la pauta: si queremos conseguir la emergencia de una especie de humano altamente delicado y espiritualizado (identificado plenamente con la belleza del arte y de la filosofía), apliquemos la fórmula de la quinta de la Sabina: ahí va el poeta no a refugiarse cobardemente de los peligros de la realidad cotidiana, sino a cribar y acrisolar todos los materiales en bruto que extrajo de su contacto con los demás seres humanos. Nada le es ajeno al ppeta: plazas y mercados, templos y academias, estadios y teatros... El resultado subsiguiente es arte y reflexión vertidos en palabras o en notas musicales.

Es posible, entonces, que de ese retiro (experimental) salga un mutante - Horacio lo consiguió-: una especie de homúnculo como el creado por Wagner, el fámulo de Fausto; un prototipo, un adelanto de lo que podría ser el humano del futuro: anclado fuertemente en lo terreno, gozando a rabiar de todas las bellezas (y aun sufriendo los sinsabores) de lo camal; pero también altamente volatilizado, capaz de sustraerse a gozar de las delicias de lo supraterreno, representado por la música, la poesía y la meditación reposada... La carne de este nuevo ser será a ratos visible, a ratos invisible: tan familiarizado estará con todas las manifestaciones que ahora desconocemos del espíritu y de la psique humana.

Yo estoy dispuesto a llevar a cabo el experimento en mi Arboleda. Como un aprendiz de brujo, me asomo apenas a los magnos resultados de los Maestros; pero me gozo de estar experimentando siquiera réplicas menores de aquellos resultados magníficos. Pero viene ahora el riesgo que constituye el medio circundante. En El Salvador se da también alta concentración de energía: la peque- 
ñez territorial, la fuerte dendidad poblacional, unidas al relativo aislamiento cultural y económico, convierten al país en un campo experimental en donde puede estarse gestando una mutación. Y mucho me temo que esta vaya por una vía distinta a la propuesta por la quinta de la Sabina. Examinemos brevemente algunas pistas.

Decíamos antes que en El Salvador han proliferado las urbanizaciones, las casas son cada vez más numerosas, pero también más pequeñas; los patios traseros o interiores de esas casas son mínimos y casi simbólicos. Y, sin embargo, la gente parece estar conforme. Esto apunta a un fenómeno que se puede estar dando: una casa grande, con un patio enorme, parece intranquilizar a su dueño: tiene que limpiarlo, desyerbarlo, etc. Lo que generalmente se hace es ocupar esos espacios grandes para amontonar chunches, ripio y hasta basura. Total, un espacio que no se sabe manejar... Claro, entonces resultan más cómodos los patios y terrenos pequeños, y mejor si están encementados, porque no hay que pensar en cómo "llenarlos" y no se precisa de mucho tiempo para mantenerlos limpios.

Ampliemos lo anterior como si tuviéramos un pantógrafo, y tratemos de aplicarlo a lo que está sucediendo en El Salvador. Con ser de pequeñas dimensiones, el país parece haberles quedado grande a sus habitantes. Ese "patio" lleno de bosques y ríos y lagunas y barrancas, terminó por incomodar: lo vieron demasiado "enmontado" y era preferible "empequeñecerlo" y hasta encementarlo todo, de ser posible, para hacerlo y sentirlo entre las manos como algo más manejable. Así es como ha ido quedando reducido El Salvador a un avergonzante Lilliput: a la medida de las estrechas y enanas dimensiones del horizonte mental y espiritual de sus habitantes. Así va entrando El Salvador al nuevo milenio: cada vez más cercano al ideal "utópico" de convertirse en un megacentro comercial, rodeado de infinitos parqueos y "adomados" con árboles y plantas de plástico.

Aquí en este país donde el hacinamiento y la superconcentración urbana exacerban la violencia y el asco de toparse siempre con las mismas gentes; aquí, donde están privilegiando cada vez más la "viveza" y la "inteligencia" de quienes hacen los negocios más lucrativos sin importar los costos morales y sociales; aquí puede estarse gestando una mutación, un prototipo de humano para el futuro; quizás cada vez menos de came y hueso: en lugar de extremidades inferiores habrá de tener llantas de hule; con órganos y prótesis de plástico y durapax, y con un cerebro tan rígido como un plafón.

Si no logramos crear quintas Sabinas, si no logramos fabricar ínsulas donde sea posible la gestación de seres verdaderamente humanos; entonces, El Salvador va a seguir produciendo explosivos cada vez más potentes y devastadores; ayer fue la guerra civil, hoy la delincuencia, mañana ¿qué será? Si no nos responsabilizamos, no por cambiarle el rumbo a esta nave, - porque eso es ya 
prácticamente imposible - si no por fabricar botes salvavidas, pues entonces nos iremos todos al despeñadero.

\section{Acodo. Un orfanatorio colmado de huéspedes}

Terminaba el capítulo I de este trabajo, "El SOS de algunas plantas", diciendo que en mi Arboleda sólo quedaban unas seis orquídeas "huérfanas", y que ojalá con ellas pudiera salvar la especie. Cuál no sería mi sorpresa, cuando por esos días en que escribía el capítulo, me "saltaron" prácticamente a la vista decenas de orquídeas del mismo tipo de mis "huérfanas". Lo curioso es que por ese lugar pasaba yo tres y cuatro veces al día, y no había notado nunca la presencia de ellas, hasta ese momento... ¿Casualidad? yo sé que no... para mí fue como un premio: "-Y Ya que tanto te has preocupado por nosotras; aquí estamos... Tomanos y llevanos hasta tu arboleda". Ahora, mi terreno parece ya un "orfanatorio": por muchos lugares se encuentra uno con un pequeño tronco plagado de "huérfanas". La especie parece estar salvada, por ahora.

En la medida de lo posible, mi experiencia de jardinero la voy aplicando a muchos aspectos de mi vida, tal como conté antes. Terminaré este trabajo explicando cómo mi labor de escritor se beneficia de aquella experiencia hasta en los más mínimos detalles. Conté antes que con mi hijo Cayo construimos, poco a poco, unos arriates alrededor de los árboles. La "técnica" es la siguiente: ladrillos de obra, partidos por la mitad, colocados en filas formando circunferencias u otras figuras caprichosas; entre ladrillo y ladrillo echamos cemento dejando un espacio como de $5 \mathrm{~cm}$. Luego, lavamos bien los ladrillos para que no quede mezcla sobre ellos, y dejamos que se seque el cemento. A los dos días, el arriate está ya listo para ser rellenado de tierra abonada que sacamos de algún lugar del terreno. Enseguida viene la operación de la siembra de las plantas: colas de ardilla, platanillos, hojas de la suerte, teléfonos, piñitas moradas y otras son colocadas de acuerdo a cierto orden; termino la operación colmando los espacios vacíos con centavito de tres clases: desde el menudito que tiene hojitas de menos de $1 \mathrm{~cm}$., hasta el gigante con hojas afelpadas que pueden llegar a tener hasta $7 \mathrm{~cm}$. y más de diámetro.

Para que las plantas se peguen y "agarren puesto" no tiene que pasar mucho tiempo: casi al mes el arriate luce como si siempre hubiera estado ahí: rebosante de verdor y colorido, como una gigantezca canasta tropical.

Pues bien, la misma "técnica he utilizado para alguno de mis trabajos escritos: este, por ejemplo, ha sido diseñado de acuerdo a aquel sistema de "arriates": cada uno de los capítulos es como un arriate: los ladrillos están representados por ideas independientes que van formando fila; el cemento: todas las frases y palabras (como que la sintaxis es, precisamente, eso: unión, eslabonamiento) que unen y vinculan las ideas; la tierra abonada es todo el material temático que integra el contenido, y las plantas con flores que lo adoman estarían representadas por las "florituras" del estilo. 
A mí me funciona visualizar así mi escrito: con capítulos-arriates como unidades que conservan cierta independencia pero que, a la postre, también conforman un mismo "jardín", una misma "Arboleda". En una próxima entrega daré cuenta de otros "arriates" más con que pienso ir ampliando mi patrimonio.

Antiguo Cuscatlán, 27 de octubre de 1998. 